\title{
Detection of Ug99 (TTKSK) of wheat stem rust fungus and new virulence races of Puccinia graminis f.sp. tritici in Egypt
}

\section{Shahin A A* • Youssif W • EL-Naggar Doaa}

Received: 05 July 2020 / Accepted: 27 July 2020 / Published online: 21 August 2020

(C) Egyptian Phytopathological Society 2020

\begin{abstract}
Wheat stem rust caused by Puccinia graminis f. sp. tritici (Pgt), is one of the most destructive diseases of wheat. Survey of stem rust was carried out during 2014 and 2015 seasons in Kafrelsheikh, Sharqia, and Nubaria governorates in Egypt. The physiologic races of stem rust were determined on seedlings of the standard wheat stem rust differentials following the international system of nomenclature. Results indicated the occurrence of twelve races, three in the Ug99 race group; TTKST, TTKTK, TTKSK from Al-Sharqia, Sakha and from Nubaria, respectively. The rest of races are not belonging to the Ug99 race group which was detected during the two seasons. In addition, situation was studied on monogenic $S r$ 's lines against stem rust disease under field conditions. $S r 2$, $S r 24$ and $S r 26$ were highly effective for resistance in both seasons. While, Sr27 and Sr31 either was ineffective in some years, or did not confer adequate resistance. Four Egyptian wheat germplasm namely Giza164, Sakha93, Sakha94 and Sids1 with significantly low ACI, AUDPC, rAUDPC and RRI were identified. Also, these genotypes showed low disease severity moderately resistance (MR) infection type in both seasons. First occurrence of the Ug99 race of wheat stem rust $(P g t)$ to Egypt in 2014/15. The obtained results would serve as a fruitful tool in wheat breeding program directed for disease resistance.
\end{abstract}

Keywords: Wheat stem rust; Ug99 race group; Physiological races; Sr31 virulence; Egypt.

\footnotetext{
* Correspondence: Shahin A A

a.a.shahin@hotmail.com
}

\section{Shahin A A}

Wheat Disease Research Department, Plant Pathology Research Institute, Agricultural Research Center, 12619 Giza, Egypt

\section{Youssif W}

Wheat Disease Research Department, Plant Pathology Research Institute, Agricultural Research Center, 12619 Giza, Egypt

\section{EL-Naggar Doaa}

Wheat Disease Research Department, Plant Pathology Research Institute, Agricultural Research Center, 12619 Giza, Egypt

\section{Introduction}

Wheat stem rust caused by Puccinia graminis f. sp. tritici $(P g t)$ play an important role in wheat production throughout the world with other rust diseases of wheat. Wheat (Triticum aestivum L.) is one of the world's leading cereal grains used by more than one-third of its population as a staple food and contributes more calories and proteins to the world diet than any other cereal crops (Curtis, 2002). Wheat national production-consumption gap is a major economy dilemma in Egypt, where $49 \%$ of wheat national consumption was imported in 2013 and it will reach $63 \%$ under climate change in 2030 (Ouda and Zohry, 2017). The major biotic factors that limit wheat production in the country include diseases, insect pests and weeds (Abebe et al., 2012). Stem rust (Pgt), leaf rust $(P$. triticina) and stripe rust ( $P$. striiformis $\mathrm{f}$. $\mathrm{sp}$. tritici) are the most important diseases reducing wheat production in the world as well as Egypt (Shahin, 2002 \& Singh et al., 2008). Pgt was established by Stakman and Levine (1922) as the first key assigned for wheat stem rust races which was based on differential reaction of the wheat cultivars. The key was revised several times, two major events pronouncedly affected changes in classification of Pgt. The first one was development of gene for gene concept 
adopted by Flor (1971) while the second was the occurrence of wheat genotypes carrying single genes (Knott and Anderson, 1965 \& Luig and Latter, 1983). The recent race nomenclature system was assigned by Roelfs and Martens (1988). An international system of nomenclature for $\mathrm{Pgt}$ that should facilitate worldwide communication between breeders and pathologists was established. The above mentioned system permits an evaluation of cultures in the area of origin and a complete phenotypes description of the type submitted to the Cereal Rust Laboratory adopted by Roelfs and Martens (1988). Shahin (2002) and Youssef (2012) used identification in the Pgt-code letter to determine wheat stem rust races in Egypt.

Epidemics of stem rust of wheat often occur in different parts of the world. In Egypt, the first epidemic occurred during 1947 when stem rust severely attacked the wheat varieties such as Hindi and Tosson, while, the last epidemic existed in 1987, when growing the highly susceptible varieties to stem rust i.e., Sakha79 and Sakha8, the highest loss was recorded with the susceptible varieties $33.5 \%$ in grain yield due to early stem rust infection (Abd El-Hak et al., 1982; El-Daoudi et al., 1987 and Bassiouni et al., 1987). Over the last 20 years, reasonable worry is caused by spread of the aggressive races of $P g t$, that has been detected in Uganda in 1999 namely Ug99 (abbreviation of "Uganda 1999") (Pretorius et al., 2000 and Singh et al., 2008; 2011). Under favorable conditions, stem rust epidemics have resulted in about $50 \%$ yield losses in recent years, whereas yield losses due to Ug99 can be as high as $90 \%$ (Beard et al., 2006). The stem rust pathogen is capable to rapidly develop a new virulence to resistance genes owing to mutations and genetic recombination.

It has also been shown that the race is very virulent to most known resistant genes globally (Singh et al., 2008). Recent evidence has indicated that a $\mathrm{Yr}$ - -virulent $P$. striiformis race was first evolved in Eastern Africa and then migrated to South Asia through Arabian Peninsula, North Africa, Middle East and West Asia through 10 years and caused severe epidemics in its migration track (Singh et al. 2004). Several important cultivars in those areas are susceptible to Ug99 race and could cause severe losses if Ug99 follows a migration patterns similar to that of P. striiformis (Sing et al., 2004). Recently, Ug99 has spread throughout East Africa, Yemen, Sudan, Iran and Egypt. Its spread has been predicted toward North Africa, Middle East Asia, and beyond, raising serious worrying concerns of major epidemics that could destroy wheat crops in various areas (Singh et al., 2011). Variant strain of Ug99 and TTKST were detected in Kenya and Egypt in 2006, 2007 and 2015 indicating the evolution of Ug99 (Patpour et al., 2016).
Monogenic lines of resistance genes $\operatorname{Sr} 13,22,24,25,26$, $27,28,32,33,35,36,39,40,44, T m p$, and Tt-3 were effective against TTKS both at seedling and adult plant stages (Jin et al., 2007). Wheat stem rust can be effectively controlled by cultivating resistant varieties. However, the development of resistant varieties requires knowledge of the pathogen population, virulence diversity and race distribution in particular region and time, since resistance genes are effective against those races. Thus, monitoring of the races and their virulence surveys are important aspect of forecasting the virulence shifts in a population and the disease management strategy to avoid crop losses.

CIMMYT scientists efforts in the searching for effective sources of resistance from readily accessible gene pools of new sources of resistance from alien gene pools. Also, Marker haplotypes identified for most sources of resistance, multiple linkage blocks of two or more resistance genes to enhance gene pyramiding efforts. Robust DNA markers for $\mathrm{Sr} 25$ were identified (Liu et al., 2010), enabling selection of this Thinopyrum ponticumderived alien resistance on chromosome 7DL. CIMMYT wheat germplasm containing $S r 25$, and presumably $\operatorname{Lr} 19$, in combination with $\mathrm{Sr} 2$ was recently released in Egypt (Misr1 and Misr2), in Afghanistan (Muqawim 09), and in Pakistan (NR356).

The Egyptian wheat program is good of preparedness for the Ug99 threat, being the first country to release cultivars resistant to Ug99 (Misr1 and Misr2) (CIMMYT, 2009). The two wheat genotypes; Misr1, and Misr2 became susceptible to infection type reaction reach to $30 \mathrm{~S}$ under field conditions, which could serve as the reemergence for new physiological races of stem rust that can attack resistant cultivars in Egypt. Taking into consideration the above mentioned issue, the objective of this study was to identify wheat stem rust races of isolates obtained from different regions of Egypt. Also, to evaluate reaction of the differential set, monogenic line and Egyptian wheat genotypes to well-identify the virulence of yellow rust pathogen and determine the effectiveness of resistance genes.

\section{Materials and methods}

The present investigation was performed in the greenhouse and at the experimental farm of Wheat Disease Research Department, at Sakha Agriculture Research Station, Kafrelsheikh, (31 ${ }^{\circ} 5^{\prime} 12^{\prime \prime}$ North, 30 $36^{\prime}$ 49" East), Plant Pathology Research Institute (PPRI), Agriculture Research Center (ARC), Egypt during 2014/15 and 2015/16 growing seasons. The annual survey of stem rust was carried out during 2014 growing seasons, included trap nurseries in some of the Egyptian governorates i.e. Kafrelsheikh $\left(31.094059^{\circ} \mathrm{N}, 30.933899^{\circ} \mathrm{E}\right)$, Al-Sharqia $\left(30.601400^{\circ} \mathrm{N}, 31.510383^{\circ} \mathrm{E}\right)$, and Nubaria $\left(30.91464^{\circ} \mathrm{N}\right.$, 
$\left.29.95543{ }^{\circ} \mathrm{E}\right)$. The collected samples showed the identical symptoms of stem rust on stems and leaf sheath. Samples of infected stems were cut into small pieces of $5-10 \mathrm{~cm}$ in length using scissors and placed in paper bags after the samples were separated from the stem in order to keep stem and/or leaf sheath dry. In April 2014/15 growing season, high levels of stem rust infection were observed on entries in wheat grown in a nursery at Sakha Agricultural Research Station on wheat cultivars, i.e. PBW343, and (Benno)/6*LMPG-6 DK42 which are known to carry stem rust resistance $\mathrm{Sr} 31$. The same observation was found in Sharqia and Nubaria locations. Collected samples included stems and/or leaves of wheat showing characteristic symptoms of stem rust disease from an annual survey of wheat genotypes carrying $\mathrm{Sr} 31$.

These samples were tested in the greenhouse at Sakha for stem rust resistance genes using inoculation of 'Quicksets' with the bulk samples for virulence for $\mathrm{Sr} 24, \mathrm{Sr} 31$ and $\mathrm{Sr} 36$ in addition to the susceptible check variety (Morocco). These "Quicksets" were used as quick and preliminary testing under greenhouse conditions to detect presence of Ug99 (or race TTKSK) in Egypt. Samples were collected and sent under permit to two independent international rust laboratories namely international cooperation with Global Rust Reference Center (GRRC, Denmark) and the USDA-ARS Cereals Disease Laboratory, (Minnesota, USA). The pathotyping was repeated in three independent experiments using singlepustule isolates in GRRC. In addition, isolates were determined and analyzed collected samples for the considered isolates carrying Sr31-virulence by using DNA/PCR in the USDA-ARS (CDL), for an independent confirmation of the identification stem rust races predominant in Egypt particularly in the Northern governorates of Egypt during the two growing season 2014 and 2015.

Urediniospores were recovered on susceptible wheat cv. Morocco and McNair 701. Single pustule isolates were derived and analyzed at GRRC and USDA-ARS (CDL), respectively, using 20 North American stem rust differential lines following standard race-typing procedure (Jin et al., 2008). In addition, three supplemental tester lines of Siouxland (carrying Sr24+Sr31), Sisson (carrying $\operatorname{Sr} 31+\operatorname{Sr} 36$ ) and Triumph 64 (donor of SrTmp) were included to confirm virulence/avirulence to $\mathrm{Sr} 24$, Sr31, Sr36 and SrTmp.

To identify the physiologic races the methods of Roelfs and Marten (1988) were followed. In particular, the samples were collected in paper bags, labeled and sent to Wheat Disease Research Department (Sakha) laboratory and the above mentioned international labs for analysis to be increased and purified. Total of stem rust samples (in the two growing seasons) were collected and the method of Stakman et al. (1962) was precisely used, since the preserved samples were multiplied on the highly susceptible check "Little Club". Then, increased samples were purified using the single pustule technique, since 3-5 single pustules were picked up and increased in single isolated pots and allowed to be increased to be utilized for race identity.

Seedlings 7-10 days-old of the differentials were inoculated using the rubbing technique after the removal of the waxy layer. The inoculated seedlings were moistened and put in the apparatus at $20-24{ }^{\circ} \mathrm{C}$ for $24 \mathrm{hr}$. in dankness under moisture stress of $100 \%(\mathrm{RH})$. The incubated seedlings were transferred to growth cabinets under the day light intensity and left for 10-12 days, till the symptoms could be visually recognized. Disease reactions were determined according to the (0-4) scale adopted by Stakman et al. (1962) in which symptoms specifications are clarified.

The races were nomenclature based on the differential reactions of rust isolates across the standard differentials. The infection types and infection classes corresponding varietal reactions were the same as described previously (Stakman et al., 1962). Race designation was done by grouping the differential hosts into five subsets in the following order: (i) $\mathrm{Sr} 5, \mathrm{Sr} 21, \mathrm{Sr} 9 e, \mathrm{Sr} 7 b$; (ii) $\mathrm{Sr} 11, \mathrm{Sr} 6, \mathrm{Sr} 8 a, \mathrm{Sr} 9 g$; (iii) $\operatorname{Sr} 36, \operatorname{Sr} 9 b, \operatorname{Sr} 30, \operatorname{Sr} 17$; (iv) $\operatorname{Sr} 9 a, \operatorname{Sr} 9 d, \operatorname{Sr} 10, \operatorname{SrTmp}$; and (v) $\mathrm{Sr} 24, \mathrm{Sr} 31, \mathrm{Sr} 38$, and $\mathrm{SrMcN}$ (Roelfs and Martens 1988) (See Tables 1-4).

\section{Evaluation of monogenic lines $S r^{\prime} s$ and Egyptian wheat genotypes under field conditions}

Experiments were conducted at Sakha Agricultural Research Station in Kafrelsheikh and Sharqia during the 2014/15, and 2015/16 growing seasons. The seeds of 47 wheat genotypes including differentials and isogenic lines were received from the International Center for Agricultural Research in the Dry Areas (ICARDA) with known stem rust resistance genes. In addition to, 47 wheat entries representing the Egyptian wheat germplasm (T. aestivum L.) as well as susceptible check variety; Morocco were received from the Department of Wheat Research, Field Crops Institute, ARC were chosen for this study. The differential sets, isogenic lines and 47 Egyptian wheat entries were planted in two $1.5 \mathrm{~m}$ rows spaced $30 \mathrm{~cm}$ apart. Three grams of seeds were adequate for each experiment and broadcasting method was applied. Susceptible check Morocco was planted after every 10 entries around the border of the nursery. Wheat genotypes were tested against stem rust and the resistance was assessed at adult plant stage. 
Table 1 List of twenty wheat stem rust differential host varieties with their corresponding $S r$ genes and origin/pedigree

\begin{tabular}{lll}
\hline Single-gene line & Sr gene & Origin/Pedigree \\
\hline ISr5-Ra & 5 & Summit \\
T. mono. derivative & 21 & Einkorn CI 2433 \\
verstein & $9 \mathrm{e}$ & Vernal \\
ISr7b-Ra & $7 \mathrm{~b}$ & Red Fife \\
ISr11-Ra & 11 & Gabo \\
ISr6- Ra & 6 & McMurachy \\
ISr8- Ra & $8 \mathrm{a}$ & Mentana \\
CnSSr9g & $9 \mathrm{~g}$ & Kubanka \\
W2691SrTt-1 & $36(\mathrm{Tt}-1)$ & Idaed 59 \\
W2691Sr9b & $9 \mathrm{~b}$ & Gamenya \\
BtSr30Wst & 30 & Festiguay \\
Combination VII & 17 & Regent \\
ISr9a-Ra & $9 \mathrm{a}$ & Red Egyptian/Chinese Spring \\
ISr9d-Ra & $9 \mathrm{~d}$ & Hope/Chinese Spring \\
W2691Sr10 & 10 & Marquis*4/Egypt NA95/2/2*2691 \\
CnSSrTmp & Tmp & Triumph 64(Cl 13679)/Chinese Spring \\
LcSr24Ag & 24 & Little Club/Agent CI13523 \\
Sr31(Benno)/6*LMPG & 31 & Kavkaz \\
Trident & 38 & Spear*4/VPM(PI519303) \\
McNAIR 701 & McN & CI 15288 \\
\hline Sol & & \\
\hline
\end{tabular}

Source: ICARDA, 2011/12.

Table 2 Infection types produced by physiological races of $P g t$ on standard differential varieties of Triticum spp

\begin{tabular}{|c|c|}
\hline $\begin{array}{c}\text { Infection } \\
\text { type }\end{array}$ & Varietal reactions and reaction classes \\
\hline & Resistant \\
\hline 0 & IMMUNE - No uredia nor other indications of infection \\
\hline 0 ; & NEARLY IMMUNE - No uredia, hypersensitive flecks present \\
\hline 1 & VERY RESISTANT- Uredia minute; surrounded by distinct necrotic areas. \\
\hline \multirow[t]{2}{*}{2} & $\begin{array}{l}\text { MODERATELY RESISTANT- Uredia small to medium; usually in green islands surrounded by a } \\
\text { decidedly chlorotic or necrotic border. }\end{array}$ \\
\hline & Susceptible \\
\hline 3 & $\begin{array}{l}\text { MODERATELY SUSCEPTIBLE - Uredia medium in size; coalescence infrequent; no necrosis, but } \\
\text { chlorotic areas may be present, especially under unfavorable growing conditions. }\end{array}$ \\
\hline 4 & $\begin{array}{l}\text { VERY SUSCEPTIBLE - Uredia large, and often coalescing; no necrosis, but chlorosis may be present } \\
\text { under unfavorable growing conditions }\end{array}$ \\
\hline \multirow[b]{2}{*}{$\mathrm{x}$} & Mesothetic \\
\hline & $\begin{array}{l}\text { HETEROGENEOUS - Uredia variable, sometimes including all infection types and intergradations between } \\
\text { them on the same leaf; no mechanical separation possible; on reinoculation small uredia may produce large } \\
\text { ones, and vice versa. }\end{array}$ \\
\hline
\end{tabular}


Table 3 Pgt-code for the $20[P g t]$ differential host varieties for Pgt in order subsets of five

\begin{tabular}{|c|c|c|c|c|c|}
\hline \multirow[b]{2}{*}{ Pgt-code } & \multirow{2}{*}{$\begin{array}{l}\underline{\text { Subset }} \\
1 \\
2 \\
3 \\
4 \\
5\end{array}$} & \multicolumn{4}{|c|}{ Infection type produced on host lines with $\mathrm{Sr}$} \\
\hline & & $\begin{array}{l}5 \\
11 \\
36 \\
9 a \\
24\end{array}$ & $\begin{array}{l}21 \\
6 \\
9 b \\
9 d \\
31\end{array}$ & $\begin{array}{l}9 e \\
8 a \\
30 \\
10 \\
38\end{array}$ & $\begin{array}{l}7 b \\
9 g \\
17 \\
T m p \\
M c N\end{array}$ \\
\hline B & & Low & Low & Low & Low \\
\hline $\mathbf{C}$ & & Low & Low & Low & High \\
\hline D & & Low & Low & High & Low \\
\hline $\mathbf{F}$ & & Low & Low & High & High \\
\hline $\mathbf{G}$ & & Low & High & Low & Low \\
\hline $\mathbf{H}$ & & Low & High & Low & High \\
\hline $\mathbf{J}$ & & Low & High & High & Low \\
\hline $\mathbf{K}$ & & Low & High & High & High \\
\hline $\mathbf{L}$ & & High & Low & Low & Low \\
\hline $\mathbf{M}$ & & High & Low & Low & High \\
\hline $\mathbf{N}$ & & High & Low & High & Low \\
\hline $\mathbf{P}$ & & High & Low & High & High \\
\hline $\mathbf{Q}$ & & High & High & Low & Low \\
\hline $\mathbf{R}$ & & High & High & Low & High \\
\hline $\mathbf{S}$ & & High & High & High & Low \\
\hline $\mathbf{T}$ & & High & High & High & High \\
\hline
\end{tabular}

L=low ITs (0 to 2+), H=high ITs (3- to 4).

Table 4 Twelve stem rust samples collected from Egypt and studied for virulence

\begin{tabular}{ccccc}
\hline Code & Host Varity & Sample season & Location & Infection \\
\hline 14EGY001 & (Benno)/6*LMPG-6 DK42 & $2014 / 15$ & Sharqia & MS \\
14EGY002 & (Benno)/6*LMPG-6 DK42 & $2014 / 15$ & Sharqia & MS \\
14EGY003 & PBW343(8STEMRRSN) & $2014 / 15$ & Sakha & MR-MS \\
14EGY004 & PBW343(GENETIC STOCK) & $2014 / 15$ & Sakha & MR-MS \\
14EGY005 & PBW343(IBWSN) & $2014 / 15$ & Sakha & MS-S \\
14EGY006 & (Benno)/6*LMPG-6 DK42 & $2014 / 15$ & Sharqia & MS \\
15EGY007 & Misr1 & $2015 / 16$ & Nubaria & S \\
15EGY008 & Misr1 & $2015 / 16$ & Nubaria & S \\
15EGY009 & Giza168 & $2015 / 16$ & Nubaria & S \\
15EGY010 & Giza171 & $2015 / 16$ & Nubaria & S \\
15EGY011 & Misr1 & $2015 / 16$ & Sakha & S \\
15EGY012 & Misr2 & $2015 / 16$ & Sakha & S \\
\hline
\end{tabular}

*Isolate name consists of three pars, first, two values denote year of collection eg. 14=2014, 15=2015 and 16=2016, second letters; EG denotes country, third part denotes isolate number.** ITs based on Roelfs et al. (1992)., 0=Immune. $R=$ resistant (necrosis with few uredinia); MR = moderately resistant (necrosis with small to moderate number of uredinia); MS = moderately susceptible (moderate number of uredinia with chlorotic areas); and $\mathrm{S}=$ susceptible (large number of uredinia, no necrosis but chlorosis may be evident). 


\section{Disease Scoring}

Disease severity (percentage of rust infection on the plant) and field response (type of disease reaction) were recorded. Disease severity was recorded as a percentage according to the modified Cobb scale. Infection response was rated as the host response based on Roelfs et al., (1992) scale including [R= (Resistant: visible chlorosis or necrosis, no uredia are present), $\mathrm{MR}=$ (Moderately Resistant: small uredia are present and surrounded by either chlorotic or necrotic areas), MS= (Moderately Susceptible: medium sized uredia are present and possible surrounded by chlorotic areas), and $\mathrm{S}=$ (Susceptible: large uredia are present, generally with little or no chlorosis and no necrosis)].

The disease severity scores were converted into area under disease progress curve (AUDPC) values following Pandey et al. (1989) formula as follows:

$\mathrm{AUDPC}=\mathrm{D}\left[1 / 2\left(\mathrm{Y}_{1}+\mathrm{Y}_{\mathrm{k}}\right)+\mathrm{Y}_{2}+\mathrm{Y}_{3}+\ldots .+\mathrm{Y}_{\mathrm{k}-1}\right]$ whereas, $\mathrm{D}=$ Time interval (days between reading), $\left(\mathrm{Y}_{1}+\mathrm{Y}_{\mathrm{k}}\right)=$ Sum of first and last disease scores. $\left(\mathrm{Y}_{2}+\mathrm{Y}_{3}+\right.$ $\left.\ldots+Y_{k-1}\right)=$ Sum of all in-between disease scores.

The relative percentage of AUDPC for each entry was calculated by setting AUDPC of Morocco as 100 percent (Ma et al., 1995). To determine the different categories of resistance, the germplasm having rAUDPC value ranging between $0-10$ was categorized as resistant; $11-30$ as intermediate and above 30 were considered as highly susceptible, to obtain the relative AUDPC (rAUDPC) in the following formula:

rAUDPC $=[$ genotypes AUDPC $/$ susceptible check AUDPC] $\times 100$

The highest ACI of a candidate line was set at 100 and all other lines were adjusted accordingly. This gives the Country Average Relative Percentage Attack (CARPA). The ' 0 ' to ' 9 ' scale previously designated as Resistance Index (R.I) has been re-designated as RRI (Relative Resistance Index). From CARPA, RRI was calculated on a 0-9 scale, where 0 denotes most susceptible and 9 denotes highly resistant (Akhtar et al., 2002). The RRI was calculated according to the following formula:

$$
\mathrm{RRI}=[100-\mathrm{CARPA}] / 100 \times 9
$$

The coefficient of infection (CI) was obtained by multiplying the final disease severity for each individual score by the numerical value where $\mathrm{TR}=0.1 ; \mathrm{R}=0.2$; $\mathrm{MR}=0.4 ; \mathrm{M}=0.6 ; \mathrm{MS} 0.8$ and averaged to give average coefficient of infection (ACI) (Roelfs et al., 1992).

\section{Statistical analysis}

All experiments were performed twice to three times with three replications for each wheat genotypes used in the greenhouse and field tests. The obtained data were statistically analyzed using MSTAT-C program version 2.10 (1991). Least significant difference (LSD) was employed to test the significant difference between wheat genotypes at $\mathrm{P} \leq 0.05$ (Gomez and Gomez, 1984).

\section{Results}

\section{Physiological races and virulence of wheat stem rust in Egypt}

The obtained results gave evidence to presence of $\mathrm{Sr} 24$ and Sr31-virulent of Pgt from the perspective of using inoculation of Quicksets' with the bulk samples for virulence for Sr24, Sr31 and Sr36 under greenhouse condition at Sakha Agriculture Research station, Egypt. In addition, preliminary results confirmed presence of Sr31-virulent was supported by three independent observations. Twelve races of Pgt were identified from samples collected in 2014 season, which have a wider range of virulence spectrum on wheat differential hosts. Regarding trap nurseries samples, 82 isolates were used for race analysis from different governorates in Egypt. Using the international system of nomenclature for Pgt, 12 races were identified based on their reaction on 20 differential hosts indicating a high level of variation.

Among 12 races, the most frequent and predominant races identified were TTTTF, TKKTF and TTKTK with a frequency of $28.00 \%, 26.80 \%$ and $15.90 \%$, respectively. The second most frequent race were TKSTB, TKRTC, TTKST and TTKSK with a frequency of $11.00 \%, 4.88 \%, 4.88 \%$ and $2.44 \%$, respectively. Conversely, the remaining 5 races were detected only once each with a frequency of $1.22 \%$ (Table 5).

The 12 races identified had wide virulence spectra. The study of virulent races using the international system of nomenclature for Pgt races on 20 differential hosts indicated that the most virulent races were TTKST, TTKTK and TTTTF making 18 stem rust resistance genes ineffective except (Sr36, and $S r T m p)$, (Sr36, and $S r 24)$ and (Sr24 and Sr31), respectively. Races TTKSK, TKTTF and TTKTF were virulent to 17 differential hosts resistance genes except (Sr11, Sr24, and $S r 31)$, (Sr36, SrTmp and Sr24) and (Sr36, Sr31 and Sr31), respectively. While, races TKKTF, TTTTB and TTKTC, which are virulent to $16 \mathrm{Sr}$-genes out of $20 \mathrm{Sr}$ genes studied, followed by TKRTC (virulent to $15 S r$-genes) and TKSTB (virulent to $14 \mathrm{Sr}$-genes).

On the other hand, race TCMLC (9Sr-genes) exhibited the least number of susceptible responses of stem rust resistance genes. The virulence \% of stem rust races identified ranged from $1.22 \%$ to $28.00 \%$. Three races i.e. TTKST, TTKTK and TTTTF were the most virulent ones, since they showed $90 \%$ each one of the stem rust resistance genes followed by, three races TTKSK, TKTTF and TTKTF showed 85\% virulence each one. 
Table 5 Races, its virulence of $P g t$ collected from three locations in Egypt during 2014/15 and 2015/16 growing season and its frequency

\begin{tabular}{llcc}
\hline Pgt-Code & Virulence (ineffective $\boldsymbol{S r}$ genes) & No. of isolates & Frequency \% \\
\hline TCMLC & $5,21,9 e, 7 b, 9 g, 36,17,9 a, M c N$ & 1 & 1.22 \\
TKSTB & $5,21,9 e, 7 b, 6,8 a, 9 g, 36,9 b, 30,9 a, 9 d, 10, T m p$ & 4 & 11.00 \\
TKRTC & $5,21,9 e, 7 b, 6,8 a, 9 g, 36,9 b, 17,9 a, 9 d, 10, T m p, M c N$ & 22 & 4.88 \\
TKKTF & $5,21,9 e, 7 b, 6,8 a .9 g, 9 b, 30,17,9 a, 9 d, 10, T m p, 38, M c N$ & 2 & 26.80 \\
TTKSK & $5,21,9 e, 7 b, 11,6,8 a, 9 g, 9 b, 30,17,9 a, 9 d, 10,31,38, M c N$ & 4 & 2.44 \\
TTKST & $5,21,9 e, 7 b, 11,6,8 a, 9 g, 9 b, 30,17,9 a, 9 d, 10,24,31,38, M c N$ & 13 & 4.88 \\
TTKTK & $5,21,9 e, 7 b, 11,6,8 a, 9 g, 9 b, 30,17,9 a, 9 d, 10, T m p, 31,38, M c N$ & 1 & 15.90 \\
TKTTF & $5,21,9 e, 7 b, 6,8 a, 9 g, 36,9 b, 30,17,9 a, 9 d, 10, T m p, 38, M c N$ & 1 & 1.22 \\
TTTTB & $5,21,9 e, 7 b, 11,6,8 a, 9 g, 36,9 b, 30,17,9 a, 9 d, 10, T m p$ & 23 & 1.22 \\
TTTTF & $5,21,9 e, 7 b, 11,6,8 a, 9 g, 36,9 b, 30,17,9 a, 9 d, 10, T m p, 38, M c N$ & 1 & 28.00 \\
TTKTC & $5,21,9 e, 7 b, 11,6,8 a, 9 g, 9 b, 30,17,9 a, 9 d, 10, T m p, M c N$ & 1 & 1.22 \\
TTKTF & $5,21,9 e, 7 b, 11,6,8 a, 9 g, 9 b, 30,17,9 a, 9 d, 10, T m p, 38, M c N$ & 82 & 1.22 \\
Total & - & & 100 \\
\hline
\end{tabular}

The 12 races identified had wide virulence spectra. The study of virulent races using the international system of nomenclature for $P g t$ races on 20 differential hosts indicated that the most virulent races were TTKST, TTKTK and TTTTF making 18 stem rust resistance genes ineffective except (Sr36, and SrTmp), (Sr36, and Sr24) and (Sr24 and Sr31), respectively. Races TTKSK, TKTTF and TTKTF were virulent to 17 differential hosts resistance genes except (Sr11, Sr24, and Sr31), (Sr36, SrTmp and Sr24) and (Sr36, Sr31 and Sr31), respectively. While, races TKKTF, TTTTB and TTKTC, which are virulent to $16 \mathrm{Sr}$-genes out of $20 \mathrm{Sr}$ genes studied, followed by TKRTC (virulent to $15 \mathrm{Sr}$-genes) and TKSTB (virulent to $14 S r$-genes). On the other hand, race TCMLC (9 Sr-genes) exhibited the least number of susceptible responses of stem rust resistance genes. The virulence $\%$ of stem rust races identified ranged from $1.22 \%$ to $28.00 \%$. Three races i.e. TTKST, TTKTK and TTTTF were the most virulent ones, since they showed
$90 \%$ each one of the stem rust resistance genes followed by, three races TTKSK, TKTTF and TTKTF showed $85 \%$ virulence each one. Race TCMLC was the least rank one in its virulence which showed $45 \%$ (Table 6).

\section{Virulence frequency of $\mathrm{Pgt}$ isolates to $\mathrm{Sr}$ resistance genes:}

Regarding the situation of $S r$ 's at seedling stage during 2014/15 and 2015/16 growing seasons, the effectiveness of the tested $S r^{\prime} s$, data in Table (6 and 7) indicated that Sr24 (91\% efficacy) was most effective to stem rust isolates. Likewise, Sr31, and Sr36 exhibited a considerable level of resistance $(75.00 \%$ and $50.00 \%)$, respectively. Likewise, the rest of $\mathrm{Sr}$ genes exhibited a considerable level of efficacy ranged between $(8.33 \%)$ to $(41.67 \%)$. On the other hand, $\operatorname{Sr} 5, \operatorname{Sr} 21, \operatorname{Sr} 9 e, \operatorname{Sr} 7 \mathrm{~b}, \mathrm{Sr} 9 \mathrm{~g}$ and $\operatorname{Sr} 9 a(0.00 \%)$ were the least effective ones to all stem rust isolates collected.

Table 6 Avirulence/virulence formula of 12 pathotypes of $P g t$ depending on seedling reaction of stem rust monogenic lines in 2014/15 and 2015/16 season

\begin{tabular}{lllll}
\hline Race & Year detected & No. of resistance responses & No. of susceptible responses & Virulence (\%) \\
\hline TCMLC & $2014 / 15$ & 11 & 9 & 45 \\
TKSTB & $2015 / 16$ & 6 & 14 & 70 \\
TKRTC & $2014 / 15$ & 5 & 15 & 75 \\
TKKTF & $2014 / 15$ & 4 & 16 & 80 \\
TTKSK & $2014 / 15$ & 3 & 17 & 85 \\
TTKST & $2014 / 15$ & 2 & 18 & 90 \\
TTKTK & $2014 / 15$ & 2 & 18 & 90 \\
TKTTF & $2015 / 16$ & 3 & 17 & 85 \\
TTTTB & $2015 / 16$ & 4 & 16 & 80 \\
TTTTF & $2015 / 16$ & 2 & 18 & 90 \\
TTKTC & $2015 / 16$ & 4 & 16 & 80 \\
TTKTF & $2015 / 16$ & 3 & 17 & 85 \\
\hline
\end{tabular}


Table 7 Efficacy \% of 20 Sr's evaluated against 12 pathotypes of $P g t$ during 2014/15 and 2015/16 growing seasons

\begin{tabular}{lcccc}
\hline $\boldsymbol{S r}$ 's & $\begin{array}{c}\text { No. of resistance } \\
\text { responses }\end{array}$ & $\begin{array}{c}\text { No. of susceptibility } \\
\text { responses }\end{array}$ & Efficacy \% & Virulence \% \\
\hline 5 & 0 & 12 & 0 & 100 \\
21 & 0 & 12 & 0 & 100 \\
$9 e$ & 0 & 12 & 0 & 100 \\
$7 b$ & 0 & 12 & 41.67 & 100 \\
11 & 5 & 7 & 08.33 & 58.33 \\
6 & 1 & 11 & 08.33 & 91.67 \\
$8 a$ & 1 & 11 & 0 & 91.67 \\
$9 g$ & 0 & 12 & 50.00 & 100 \\
36 & 6 & 6 & 08.33 & 50.00 \\
$9 b$ & 1 & 11 & 16.67 & 91.67 \\
30 & 2 & 10 & 08.33 & 83.33 \\
17 & 1 & 11 & 0 & 91.67 \\
$9 a$ & 1 & 12 & 08.33 & 100 \\
$9 d$ & 0 & 11 & 08.33 & 91.67 \\
10 & 1 & 11 & 25.00 & 91.67 \\
$T m p$ & 1 & 9 & 91.67 & 75.00 \\
24 & 1 & 75.00 & 8.33 \\
31 & 3 & 1 & 41.67 & 25.00 \\
$M c N$ & 11 & 3 & 16.67 & 58.33 \\
\hline
\end{tabular}

\section{Confirmation of Ug99 (TTKSK) in Egypt}

The obtained results confirmed the presence of $\mathrm{Ug} 99$ (or race TTKSK) of Pgt in Egypt. DNA/PCR test was positive for the considered isolates carrying $\mathrm{Sr} 31$ virulence, which confirmed the presence of the Ug99 race group. Three races in the Ug99 race group were detected; TTKST, TTKTK and TTKSK from Al-Sharqia, Sakha and Nubaria, respectively. This seems to be the first confirmation of races in the Ug99 race group in Egypt.

\section{Response of wheat genotypes carrying stem rust disease}

The differential sets and wheat genotypes carrying stem rust resistance genes showed a wide range of rust response during the two years-investigation under field conditions. The data obtained from the field revealed that presence of significant differences between tested entries during the two seasons. However, no significant differences were observed between regarding the two locations investigated. The performance of genotypes during 2014/15 and 2015/16 was summarized in Table 8. Resistance genes such as $\mathrm{Sr} 2, \mathrm{Sr} 24$ and $\mathrm{Sr} 26$ were effective in Kafrelsheikh and Sharqia locations and during 2014/15 and 2015/16 growing seasons. While, Sr27 either was ineffective in some years, or did not confer adequate and complete resistance to the pathogen populations. Wheat genotype; WRT 238-5 (1984) Roelfs, with resistance gene $\mathrm{Sr} 27$ showed susceptible reaction at Kafrelsheikh location during 2014/2015 growing season. Also, the genotype with $S r 31$ was moderately susceptible to susceptible during two growing seasons. Nevertheless, in the present study occurrence of virulence on previous mentioned genes in 2014/15 showed changes of the pathogen populations. In addition, the most important resistance genes i.e. $\operatorname{Sr} 25, \operatorname{Sr} 27, \operatorname{Sr} 31, \quad \operatorname{Sr} 36$ and $\operatorname{Sr} 38$, known as resistant to the previously characterized races of stem rust in Egypt became susceptible in this study, indicated continual changes of virulence in the Pgt population during 2014/15 growing season. On other hand, the rest of resistance genes tested was not effective of the pathogen populations in both years.

\section{Evaluation of the tested wheat genotypes for stem rust resistance under field condition}

This evaluation was carried out to characterize the adultplant resistance level in the tested wheat genotypes. The majority of Egyptian wheat genotypes were susceptible to moderate susceptible except varieties namely Giza164, Sakha93, Sakha 94 and Sids1 which were moderate resistant to stem rust at the adult-plant stage under field conditions, in the 2014/15 and 2015/16 growth seasons. On the other hand, most Egyptian genotypes were susceptible and their susceptibility levels were higher in Misr1, Misr2, Sakha95, Sids6 and Sids7 against Pgt populations during 2014/15 and 2015/16 growing seasons. 
Table 8 Stem rust responses of differential genotypes in Kafrelsheikh and Sharqia governorates in Egypt at adult stage over two growing seasons (2015 and 2016)

\begin{tabular}{|c|c|c|c|c|c|}
\hline \multirow{3}{*}{ Genotypes } & \multirow{3}{*}{ Genes } & \multicolumn{4}{|c|}{ Location / Season /Stem rust responses } \\
\hline & & \multirow[b]{2}{*}{$2014 / 15$} & \multirow{2}{*}{$\begin{array}{c}\text { Kafrelsheikh } \\
2015 / 16 \\
\end{array}$} & \multicolumn{2}{|c|}{ Sharqia } \\
\hline & & & & $2014 / 15$ & 2015/16 \\
\hline ISr5-Ra CI 14159 & $\operatorname{Sr} 5$ & $5 \mathrm{~S}$ & $30 \mathrm{~S}$ & $30 \mathrm{~S}$ & $30 \mathrm{~S}$ \\
\hline ISr6-Ra CI 14163 & Sr6 & $30 \mathrm{~S}$ & $40 \mathrm{~S}$ & $50 \mathrm{~S}$ & $70 \mathrm{~S}$ \\
\hline Na $101 / 6 *$ Marquis & $S r 7 a$ & $30 \mathrm{~S}$ & $40 \mathrm{~S}$ & $30 \mathrm{~S}$ & $40 \mathrm{~S}$ \\
\hline ISr7b-Ra CI 14165 & $S r 7 b$ & $30 \mathrm{~S}$ & $20 \mathrm{~S}$ & $20 \mathrm{~S}$ & $20 \mathrm{~S}$ \\
\hline CI 14167/9*LMPG-6 DK04 & Sr8a & $40 \mathrm{~S}$ & $10 \mathrm{~S}$ & $10 \mathrm{~S}$ & $10 \mathrm{~S}$ \\
\hline Barieta Benvenuto (CI 14196) & $S r 8 b$ & $60 \mathrm{~S}$ & $20 \mathrm{~S}$ & $\operatorname{TrS}$ & $\operatorname{TrS}$ \\
\hline ISr9a-Ra CI 14169 & $\operatorname{Sr} 9 a$ & $10 \mathrm{~S}$ & $30 \mathrm{~S}$ & $40 \mathrm{~S}$ & $30 \mathrm{~S}$ \\
\hline Prelude*4/2/ Marquis*6/Kenya 117A & $\operatorname{Sr} 9 b$ & $30 \mathrm{~S}$ & $60 \mathrm{~S}$ & $50 \mathrm{~S}$ & $70 \mathrm{~S}$ \\
\hline ISr9d-Ra CI 14177 & $\operatorname{Sr} 9 d$ & $30 \mathrm{~S}$ & $20 \mathrm{~S}$ & $30 \mathrm{~S}$ & $20 \mathrm{~S}$ \\
\hline Vernstein PI 442914 & Sr9e & $40 \mathrm{~S}$ & $60 \mathrm{~S}$ & $50 \mathrm{~S}$ & $70 \mathrm{~S}$ \\
\hline Chinese Spring*7/Marquis 2B & $\operatorname{Sr} 9 g$ & $\operatorname{TrS}$ & $30 \mathrm{~S}$ & $30 \mathrm{~S}$ & $30 \mathrm{~S}$ \\
\hline W2691Sr10 CI 17388 & $\operatorname{Sr} 10$ & $30 \mathrm{~S}$ & $20 \mathrm{~S}$ & $20 \mathrm{~S}$ & $20 \mathrm{~S}$ \\
\hline Lee/6*LMPG-6 DK37 & $\operatorname{Sr} 11$ & $20 \mathrm{~S}$ & $40 \mathrm{~S}$ & $\operatorname{TrS}$ & $\operatorname{TrS}$ \\
\hline Chinese Spring*5/Thatcher 3B & $\operatorname{Sr} 12$ & $60 \mathrm{~S}$ & $60 \mathrm{~S}$ & $50 \mathrm{~S}$ & $60 \mathrm{~S}$ \\
\hline Prelude*4/2/ Marquis*6/Khapstein & $\operatorname{Sr} 13$ & $20 \mathrm{~S}$ & $40 \mathrm{~S}$ & 10MSS & 20MSS \\
\hline W2691*2/ Khapstein & $\operatorname{Srl4}$ & $20 \mathrm{~S}$ & $60 \mathrm{~S}$ & $20 \mathrm{~S}$ & $30 \mathrm{~S}$ \\
\hline Prelude*2/Norka & $\operatorname{Sr} 15$ & $50 \mathrm{~S}$ & $50 \mathrm{~S}$ & $5 \mathrm{~S}$ & $20 \mathrm{~S}$ \\
\hline Thatcher/CS (CI 14173) & Sr16 & $60 \mathrm{~S}$ & $60 \mathrm{~S}$ & $5 \mathrm{~S}$ & $10 \mathrm{~S}$ \\
\hline Prelude/8*Marquis*2/2/Esp 518/9 & $\operatorname{Sr} 17$ & $30 \mathrm{~S}$ & $40 \mathrm{~S}$ & $20 \mathrm{~S}$ & $20 \mathrm{~S}$ \\
\hline Little Clube/Sr18Mq Marquis"A" & $\operatorname{Sr} 18$ & $50 \mathrm{~S}$ & $50 \mathrm{~S}$ & $30 \mathrm{~S}$ & $30 \mathrm{~S}$ \\
\hline 94A 236-1 Marquis"B" & $\operatorname{Sr} 19$ & $40 \mathrm{~S}$ & $40 \mathrm{~S}$ & $40 \mathrm{~S}$ & $50 \mathrm{~S}$ \\
\hline 94A 237-1 Marquis"C" & $\operatorname{Sr} 20$ & $50 \mathrm{~S}$ & $50 \mathrm{~S}$ & $50 \mathrm{~S}$ & $50 \mathrm{~S}$ \\
\hline McNair 701 & $\operatorname{SrMcN}$ & $60 \mathrm{~S}$ & $20 \mathrm{~S}$ & $10 \mathrm{~S}$ & $10 \mathrm{~S}$ \\
\hline T. Monococсum/8*LMPG-6 DK13 & $\operatorname{Sr} 21$ & $40 \mathrm{~S}$ & $10 \mathrm{~S}$ & $5 \mathrm{~S}$ & $10 \mathrm{~S}$ \\
\hline Mq*6//Stewart*3/RL 5244 & $S r 22$ & $50 \mathrm{~S}$ & $50 \mathrm{~S}$ & $10 \mathrm{~S}$ & $10 \mathrm{~S}$ \\
\hline Exchange CI 12635 & $S r 23$ & $10 \mathrm{~S}$ & $30 \mathrm{~S}$ & $10 \mathrm{~S}$ & $10 \mathrm{~S}$ \\
\hline $\mathrm{LcSr} 24 \mathrm{AG}$ & $\operatorname{Sr} 24$ & TrRMR & $40 \mathrm{MR}$ & 10MRMS & 20MRMS \\
\hline Agatha (CI 14048)/9*LMPG-6 DK16 & $\operatorname{Sr} 25$ & $30 \mathrm{~S}$ & $10 \mathrm{~S}$ & $10 \mathrm{~S}$ & $10 \mathrm{~S}$ \\
\hline Eagle $S r 26$ McIntosh & $\operatorname{Sr} 26$ & 5MRMS & 30MSS & 5MRMS & 10MRMS \\
\hline WRT 238-5 (1984) Roelfs & $\operatorname{Sr} 27$ & $20 \mathrm{~S}$ & $40 \mathrm{MR}$ & $\operatorname{TrR}$ & $5 \mathrm{MR}$ \\
\hline Kota RL71 & $\operatorname{Sr} 28$ & $20 \mathrm{~S}$ & $50 \mathrm{~S}$ & $20 \mathrm{~S}$ & $30 \mathrm{~S}$ \\
\hline Prelude/ $8 *$ Marquis/2/Etiole de Choisy & $\operatorname{Sr} 29$ & $20 \mathrm{~S}$ & $50 \mathrm{~S}$ & $20 \mathrm{~S}$ & $20 \mathrm{~S}$ \\
\hline Selection from Webster F3:F4 \#6 & Sr30 & $50 \mathrm{~S}$ & $30 \mathrm{~S}$ & $10 \mathrm{~S}$ & $20 \mathrm{~S}$ \\
\hline Sr31 (Benno)/6*LMPG-6 DK42 & $\operatorname{Sr} 31$ & $40 \mathrm{MS}$ & 10MSS & 20MSS & TrMSS \\
\hline ER5155 S-203 (1995) Roelfs & $\operatorname{Sr} 32$ & $10 \mathrm{MS}$ & 40MR & 10MRMS & $10 \mathrm{MS}$ \\
\hline RL 5405 (1192) Kerber & $\operatorname{Sr} 33$ & $30 \mathrm{~S}$ & $10 \mathrm{~S}$ & $5 \mathrm{~S}$ & $20 \mathrm{~S}$ \\
\hline RL 6098 (1997) Dyck & $\operatorname{Sr} 34$ & $20 \mathrm{~S}$ & $40 \mathrm{~S}$ & $20 \mathrm{~S}$ & $30 \mathrm{~S}$ \\
\hline RL 6099 (1995) Dyck & Sr35 & $40 \mathrm{~S}$ & $20 \mathrm{~S}$ & $10 \mathrm{~S}$ & $10 \mathrm{~S}$ \\
\hline W2691SrTt-1 CI 17385 & Sr36 & $30 \mathrm{~S}$ & $30 \mathrm{~S}$ & $20 \mathrm{~S}$ & $20 \mathrm{~S}$ \\
\hline Prelude*4/Line W (W3563) & Sr37 & $50 \mathrm{~S}$ & $30 \mathrm{~S}$ & $30 \mathrm{~S}$ & $30 \mathrm{~S}$ \\
\hline Trident $\operatorname{Sr} 38$ & $\operatorname{Sr} 38$ & 10MRMS & $5 \mathrm{~S}$ & $5 \mathrm{~S}$ & $5 \mathrm{~S}$ \\
\hline RL 5711 Kerber & $\operatorname{Sr} 39$ & $10 \mathrm{~S}$ & $50 \mathrm{~S}$ & $10 \mathrm{~S}$ & $10 \mathrm{~S}$ \\
\hline RL 6087 Dyck & $\mathrm{Sr} 40$ & 20MSS & $40 \mathrm{~S}$ & 20MSS & $20 \mathrm{~S}$ \\
\hline TAM 107 & SrIRS-AM & $50 \mathrm{~S}$ & $50 \mathrm{~S}$ & $5 \mathrm{~S}$ & $10 \mathrm{~S}$ \\
\hline CsSSrTmp & SrTmp & $30 \mathrm{~S}$ & $20 \mathrm{~S}$ & $10 \mathrm{~S}$ & $10 \mathrm{~S}$ \\
\hline Bt/Wld & SrWld-1 & $50 \mathrm{~S}$ & $20 \mathrm{~S}$ & $10 \mathrm{~S}$ & $10 \mathrm{~S}$ \\
\hline Pavon 76 & Sr2 complex & 5MRMS & $40 \mathrm{MR}$ & $20 \mathrm{MR}$ & 30MRMS \\
\hline
\end{tabular}

The APR has two components, \% rust severity based on the modified Cobb Scale's and response to infection as described by Roelfs et al. (1992). 
Disease severity (\%) and infection type (IT) data were combined to calculate average coefficient of infection (ACI). As indicated in Table 9, minimum or lowest ACI values (1.56) were recorded in the tested varieties namly Sakha93, Sakha94 and Mabrouk. In contrast, the highest and maximum value of ACI (79.83) was recorded for Sakha95 as well as the check variety, Morocco (89.53). Those resistance genotypes exhibited the lowest least AUDPC values (20) and least rAUDPC ratios (ranging from 2.25 to 20.13). On the other hand, the second group of genotypes includes the highly susceptible varieties; Misr1, Misr2 and Sakha95 showed the highly of AUDPC and rAUDPC values, as well as the check variety; Morocco which displayed the highest percentages of AUDPC values and highest rAUDPC values (Table 9). The obtained results of Relative resistance index (RRI) for 47 Egyptian wheat genotypes during two-year experiment were presented in Table 9. These genotypes were having highest RRI of stem rust resistance, which exhibited the highest value in varieties Sakha93 and Sakha94 (8.85). Maximum stem rust severity was recorded in Misr2, Misr2 and Sakha95 with RRI of $2.76,1.86$ and 1.82 , respectively. The check variety; Morocco displayed the highest percentages of RRI values (reached 0.94) (Table 9).

\section{Discussion}

Wheat is considered to be the essential food crop worldwide. Nearly 200 wheat diseases and pests have been documented, 50 of which are considered sufficiently important to cause economic losses (Wiese 2005). Wheat rusts in general and stem rust in particular are limiting factors of mass production of wheat. Stem rust or black rust caused by Puccinia graminis f. sp. tritici (Pgt) is a devastating disease of bread wheat (Triticum aestivum L.) and durum wheat ( $T$. durum) in the major wheat growing regions on the world.

The presented study provides few highlights on identification of physiologic wheat stem rust races. Particular, detection of variants of wheat stem rust race Ug99 in Egypt. In addition to, current status of stem rust in the inspected fields were reported and determine the effectiveness of resistance $\mathrm{Sr}$ genes under field condition in Egypt during 2014/15 and 2015/16 growing seasons. During April 2014, high levels of stem rust infection were observed on entries in wheat grown in a nursery at Sakha Agricultural Research Station, in Egypt. Samples collected from rusted stems of wheat cultivars, i.e. PBW343, and (Benno)/6*LMPG-6 DK42 are known to carry stem rust resistance $\operatorname{Sr} 31$. In the previous study, no virulence was observed on plants with genes Sr31 ((Benno)/6*LMPG-6 DK42), in trap nursery. Samples tested at Sakha
Agriculture Research station, Egypt under greenhouse condition. Singh et al. (2015) provided a recent and comprehensive overview of the status of the Ug99 race group, describing the rapid evolution of new races and its geographical expansion, with eight races reported in 13 countries. New races have continued to emerge and, by 2019, 13 had been identified (Table 10 and Fig. 1).

The identification of virulence of Pgt is very important in studying regional disease spread and the evaluation of virulence in the pathogen. Regarding the application of the nomenclature system adopted by Roelfs and Martens (1988), the obtained results gave evidence to the dominance of races TTTTF, TKTTF and TTKTK with a frequency of $28.00 \%, 26.80 \%$ and $15.90 \%$, respectively. The second most frequent race were TKSTB, TKRTC, TTKST and TTKSK with a frequency of $11.00 \%, 4.88 \%, 4.88 \%$ and $2.44 \%$, respectively. Conversely, the remaining 5 races were detected only once each with a frequency of $1.22 \%$. Similar results were obtained in other countries (Pretorius et al., 2000; Nazari et al., 2009; Abebe et al., 2012 and Kolmer et al., 2007) identified different races from collected and sent isolates of Pgt. Also, this result is in line with previous studies in Egypt (Shahin and Abu-Aly, 2015) identified 12 pathotypes of Pgt in 2012/13 growing season. Results indicated a high level of variation; races virulence showed that most virulent one race TTKTF followed by races TTKTC and TKSTB. In general, the virulence spectrum of the pathogen in this study confirmed the presence of wider range of virulence in investigated area and is in line with previous studies conducted also in Egypt (Abu El-Naga et al., 1990; Shahin, 2002 and Yousef, 2012).

Gene efficacy (\%) at seedling stage under greenhouse condition Sr's indicated that the presence of high efficacy i.e., $\operatorname{Sr} 24$ (91\% efficacy) and $\operatorname{Sr} 31$ (75\% efficacy) were effective to stem rust isolates collected followed by $\mathrm{Sr} 31$ which exhibited a considerable level of resistance (50\%). Klindworth et al. (2011) reported that stem rust differential tests coded the race TPPKC was avirulent on genes $\mathrm{Sr} 24$, Sr31 and Sr38. A comparison of the races identified in the present study revealed differences with earlier reports. This could be due to variation over location and time, as the prevalence of races in a specific season and region depends on the type of wheat cultivars grown and to some extent on the predominant environmental conditions especially temperature (Roelfs et al., 1992 \& McVey et al., 2002). 
Table 9 Adult plant infection, mean comparison for ACI, AUDPC, rAUDPC and RRI for 47 Egyptian wheat genotypes tested against stem rust disease during 2014/15 and 2015/16

\begin{tabular}{|c|c|c|c|c|c|c|}
\hline \multirow{2}{*}{ No. } & \multirow{2}{*}{ Genotypes } & \multirow{2}{*}{$\begin{array}{c}\text { Final infection } \\
\text { type }\end{array}$} & \multicolumn{3}{|c|}{ Values of disease parameters } & \multirow{2}{*}{ RRI } \\
\hline & & & ACI & AUDPC & rAUDPC & \\
\hline 1 & Misr1 & $\mathrm{S}$ & 69.63 & 500 & 38.31 & 2.73 \\
\hline 2 & Misr2 & $\mathrm{S}$ & 79.33 & 720 & 55.17 & 1.86 \\
\hline 3 & Misr3 & MRMS & 4.32 & 75 & 5.747 & 8.61 \\
\hline 4 & Giza139 & MS & 4.67 & 130 & 9.962 & 8.58 \\
\hline 5 & Giza144 & MS & 15.67 & 90 & 6.897 & 7.59 \\
\hline 6 & Giza150 & $\mathrm{S}$ & 59.33 & 550 & 42.15 & 3.66 \\
\hline 7 & Giza155 & MRMS & 5.68 & 40 & 3.065 & 8.49 \\
\hline 8 & Giza156 & $\mathrm{S}$ & 4.67 & 75 & 5.747 & 8.58 \\
\hline 9 & Giza157 & MS & 15.66 & 90 & 6.897 & 7.59 \\
\hline 10 & Giza160 & MSS & 17.63 & 150 & 11.49 & 7.41 \\
\hline 11 & Giza162 & MSS & 17.67 & 110 & 8.429 & 7.41 \\
\hline 12 & Giza163 & $\mathrm{S}$ & 4.66 & 60 & 4.598 & 8.58 \\
\hline 13 & Giza164 & MR & 7.65 & 42 & 3.218 & 8.31 \\
\hline 14 & Giza165 & MS & 7.63 & 64 & 4.904 & 8.31 \\
\hline 15 & Giza167 & $\mathrm{S}$ & 9.33 & 100 & 7.663 & 8.16 \\
\hline 16 & Giza 168 & $\mathrm{~S}$ & 29.35 & 490 & 37.55 & 6.36 \\
\hline 17 & Giza 171 & MS & 15.30 & 160 & 12.26 & 7.62 \\
\hline 18 & Sakha8 & $S$ & 36.00 & 300 & 22.99 & 5.76 \\
\hline 19 & Sakha61 & $\mathrm{S}$ & 36.33 & 475 & 36.40 & 5.73 \\
\hline 20 & Sakha 62 & $\mathrm{~S}$ & 9.33 & 165 & 12.64 & 8.16 \\
\hline 21 & Sakha 69 & $\mathrm{~S}$ & 19.50 & 215 & 16.48 & 7.25 \\
\hline 22 & Sakha88 & $\mathrm{S}$ & 59.33 & 465 & 35.63 & 3.66 \\
\hline 23 & Sakha 92 & MS & 3.76 & 120 & 9.195 & 8.66 \\
\hline 24 & Sakha93 & MR & 1.65 & 20 & 1.533 & 8.85 \\
\hline 25 & Sakha 94 & MR & 1.65 & 20 & 1.533 & 8.85 \\
\hline 26 & Sakha 95 & $\mathrm{~S}$ & 79.83 & 960 & 73.56 & 1.82 \\
\hline 27 & Gemmeiza1 & MS & 7.67 & 80 & 6.130 & 8.31 \\
\hline 28 & Gemmeiza3 & MRMS & 11.77 & 60 & 4.598 & 7.94 \\
\hline 29 & Gemmeiza5 & $\mathrm{S}$ & 36.00 & 253 & 19.39 & 5.76 \\
\hline 30 & Gemmeiza7 & MRMS & 11.83 & 80 & 6.130 & 7.94 \\
\hline 31 & Gemmeiza 9 & MS & 15.33 & 100 & 7.663 & 7.62 \\
\hline 32 & Gemmeiza 10 & MRMS & 11.67 & 80 & 6.130 & 7.95 \\
\hline 33 & Gemmeiza 11 & $\mathrm{~S}$ & 19.73 & 120 & 9.195 & 7.22 \\
\hline 34 & Gemmeiza12 & MRMS & 11.43 & 75 & 5.747 & 7.97 \\
\hline 35 & Sids1 & MR & 7.67 & 60 & 4.598 & 8.31 \\
\hline 36 & Sids2 & $\mathrm{S}$ & 29.32 & 180 & 13.79 & 6.36 \\
\hline 37 & Sids3 & $\mathrm{S}$ & 29.67 & 200 & 15.33 & 6.33 \\
\hline 38 & Sids5 & $\mathrm{S}$ & 49.13 & 580 & 44.44 & 4.58 \\
\hline 39 & Sids6 & $\mathrm{S}$ & 69.67 & 680 & 52.11 & 2.73 \\
\hline 40 & Sids7 & $\mathrm{S}$ & 69.73 & 700 & 53.64 & 2.72 \\
\hline 41 & Sids 12 & $\mathrm{~S}$ & 29.33 & 250 & 19.16 & 6.36 \\
\hline 42 & Sids13 & MS & 7.67 & 40 & 3.065 & 8.31 \\
\hline 43 & Shandweel1 & MSS & 8.66 & 36 & 2.759 & 8.22 \\
\hline 44 & Hindi62 & MS & 3.33 & 30 & 2.299 & 8.70 \\
\hline 45 & Mabrouk & MR & 1.65 & 20 & 1.533 & 8.85 \\
\hline 46 & Montana & MSS & 8.97 & 40 & 3.065 & 8.19 \\
\hline 47 & Romana & $\mathrm{S}$ & 69.67 & 400 & 30.65 & 2.73 \\
\hline 48 & Morocco & $\mathrm{S}$ & 89.53 & 1305 & 100 & 0.94 \\
\hline \multirow[t]{2}{*}{ LSD } & $1 \%$ & - & 1.811 & 5.213 & 8.410 & 0.365 \\
\hline & $5 \%$ & - & 1.364 & 3.930 & 6.356 & 0.270 \\
\hline
\end{tabular}

ACI, average coefficient of infection; AUDPC, area under disease progress curve; rAUDPC, relative area under disease progress curve; RRI, relative resistance index. 
Table 10 Puccinia graminis tritici races belonging to Ug99 lineage identified until 2019 in various countries with virulence/virulence status on discriminating resistance genes (updated from Singh et al. , 2015)

\begin{tabular}{|c|c|c|c|c|c|c|c|c|}
\hline \multirow{2}{*}{ Race } & \multirow{2}{*}{ Common alias } & \multicolumn{6}{|c|}{$\begin{array}{c}\text { Resistance genes and avirulence (A) } \\
\text { or Virulence }(\mathrm{V}) \text { status }\end{array}$} & \multirow{2}{*}{ Confirmed countries / Year detected } \\
\hline & & Sr31 & $\operatorname{Sr} 21$ & $\operatorname{Sr} 24$ & Sr36 & $S r 9 b$ & SrTmp & \\
\hline TTKSK & Ug99 & V & V & A & A & A & A & $\begin{array}{l}\text { Uganda (1998), Kenya (2001), Ethiopia } \\
\text { (2003), Sudan (2006), Yemen (2006), Iran } \\
\text { (2007), Tanzania (2009), Eritrea (2012), } \\
\text { Rwanda (2014), Egypt (2014). }\end{array}$ \\
\hline TTKSF & & A & V & A & A & A & A & $\begin{array}{l}\text { South Africa (2002), Zimbabwe (2009), } \\
\text { Uganda (2012). }\end{array}$ \\
\hline TTKST & $\mathrm{Ug} 99+\operatorname{Sr} 24$ & V & V & $\mathrm{V}$ & A & A & A & $\begin{array}{l}\text { South Africa (2006), Tanzania (2009), } \\
\text { Eritrea (2010), Uganda (2012). }\end{array}$ \\
\hline TTTSK & $\mathrm{Ug} 99+\operatorname{Sr} 36$ & V & V & A & V & A & A & $\begin{array}{l}\text { Kenya (2006), Tanzania (2009), Ethiopia } \\
\text { (2010), Sudan (2006), Uganda (2012), } \\
\text { Rwanda (2014), Egypt (2014). }\end{array}$ \\
\hline TTKSP & & A & V & V & A & A & A & South Africa (2007) \\
\hline PTKSK & & V & A & A & A & A & A & $\begin{array}{l}\text { Kenya (2009), Ethiopia (2007), Yemen } \\
\text { (2009), South Africa (2017) }\end{array}$ \\
\hline PTKST & & V & A & V & A & A & A & $\begin{array}{l}\text { Ethiopia (2007), Kenya (2008), South } \\
\text { Africa (2009), Eritrea (2010), Mozambique } \\
\text { (2010), Zimbabwe (2010) }\end{array}$ \\
\hline TTKSF+ & & A & V & A & A & $\mathrm{V}$ & A & South Africa (2010), Zimbabwe (2010) \\
\hline TTKTT & $\mathrm{Ug} 99+\operatorname{Sr} 24+\operatorname{SrTmp}$ & V & V & V & A & A & $\mathrm{V}$ & Kenya (2014) \\
\hline TTKTK & $\mathrm{Ug} 99+\operatorname{SrTmp}$ & V & V & A & A & A & $\mathrm{V}$ & $\begin{array}{l}\text { Kenya (2014), Egypt (2014), Eritrea } \\
\text { (2014), Rwanda (2014), Uganda (2014) }\end{array}$ \\
\hline TTHSK & & V & $\mathrm{V}$ & A & A & A & A & Kenya (2014) \\
\hline PTKTK & & V & A & A & A & A & A & Kenya (2014) \\
\hline TTHST & & V & V & $\mathrm{V}$ & A & A & A & Kenya (2014) \\
\hline
\end{tabular}

Note: 1 Race designation follows the North American nomenclature system described by Jin et al. 2008, Race TTKSF+ is given a temporary name as it exceeds the current North American 20 differential gene set.

The results of the present study showed that the determined reaction type of the genotypes carrying $\mathrm{Sr}$ genes from resistant (R) to susceptible (S). The adult tests clustered the wheat genotypes resistant monogenic lines (Sr2, Sr24 and Sr26). While, Sr27 was ineffective in some years, or did not confer adequate and complete resistance to the pathogen populations. Wheat genotype; WRT 238-5 (1984) Roelfs, with resistance gene $S r 27$ showed susceptible reaction at Kafrelsheikh location during 2014/2015 growing season. In addition, the genotype with Sr31 was moderately susceptible to susceptible during two growing seasons. The obvious Shifts or changes in race structure of Pgt annual populations in Egypt, could be confirmed by the relationship between them and alterations in virulence frequencies against number of Sr's genes. Among 47 Egyptian wheat genotypes, 22 varieties were susceptible (S), 5 genotypes showed moderately resistant (MR) response, 6 genotypes showed moderately resistant to moderately susceptible (MRMS), 10 genotypes showed moderately susceptible and 4 genotypes evaluated during both seasons, showed MSS infection types. Different reactions to stem rust were observed between the genotypes suggesting that the material had diverse genetic background. Also, the high frequency of MS to $\mathrm{S}$ genotypes among the genotypes suggested presence of ineffective stem rust resistance genes in their background to which the current family of Ug99 races are highly virulent (Akello et al., 2017 \& Shahin et al., 2018). The importance of this work is to supply wheat breeders with information relevant to stem rust resistance genes and ineffective genes. In addition, tracking and monitoring the changes of wheat stem rust races and their diversity. 


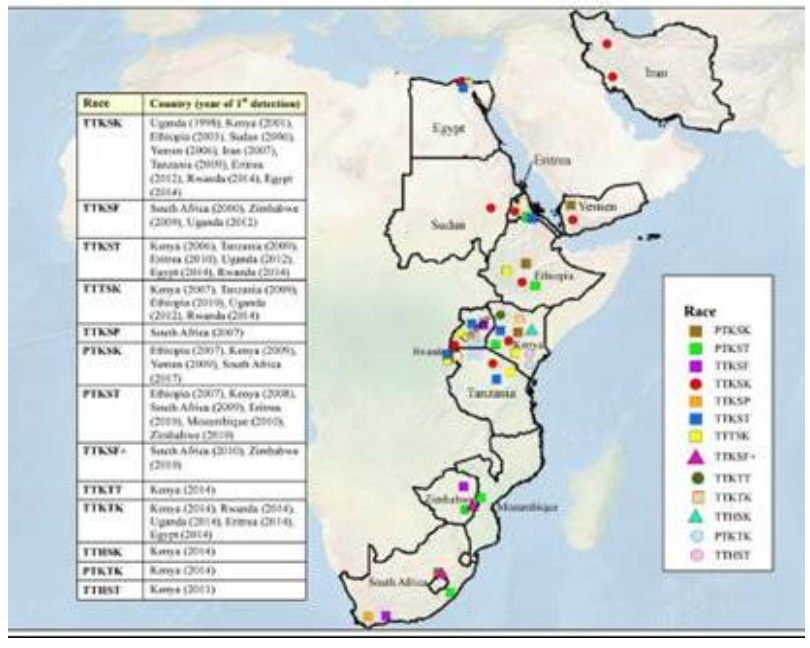

Fig. 1 Detection and distribution of Puccinia graminis tritici races belonging to $\mathrm{Ug} 99$ race group in 2019, Updated from Singh et al. 2015.

\section{Acknowledgments}

We thank the international cooperation team with the laboratories workers; Dr. Hovmøller M., and Patpour M. in the Global Rust Reference Center (GRRC, Denmark), and Dr. Jin Y., and Szabo L. in the USDA-ARS Cereals Disease Lab, Minnesota, USA to cooperate in the identification of wheat stem rust races, confirmation of Ug99 (race TTKSK) in Egypt and We thank Prof. Dr. Mustafa Azab, Field Crops Research Institute, Agriculture Research Center, Egypt for the valuable criticism and advice in the writing of the manuscript. Also, the anonymous reviewers for valuable suggestions.

\section{Conflict of interest}

The authors declare that they have no competing interests.

\section{References}

Abd El-Hak TA, El-Sherif N, Shafik I, Bassioni AA, Keddis S, El-Daoudi YH 1982. Studies on wheat stem rust virulence and resistance genes in Egypt and neighboring countries. Egyptian Journal of Phytopathology, (14): 1-10.

Abebe T, Woldeab G, Dawit W 2012. Distribution and Physiologic Races of Wheat Stem Rust in Tigray, Ethiopia. Journal of Plant Pathology and Microbiology, (3): 142.
Abu El-Naga SA, Shafik I, El-Daoudi YH, Sherif S. 1990. Virulence of Puccinia graminis tritici and genes conferring esistance in wheat. $6^{\text {th }}$ Congress of Phytopathology, Cairo March, 99-109.

Akello M, Nzuve F, Olubayo F, Macharia G, Muthomi J 2017. Identification of Resistance sources to wheat stem rust from introduced cultivars in Kenya. Journal of Agricultural Science, (9): 73-87.

Akhtar MA, Ahmad I, Mirza JI, Rattu AR, EUl-Haque Hakro AA, Jaffery AH 2002. Evaluation of Candidate lines against stripe and leaf rusts under national uniform wheat and barley yield trial 20002001. Asian Journal of Plant Sciences, 1: 450-453.

Bassiouni AA, Shafik I, El-Sherif N. El-Daoudi YH, Sherif S 1987. Effect of wheat stem rust on yield. Egyptian Journal of Phytopathology, (19): 53-60.

Beard C, Jayasena K, Thomas G. Loughman R 2006. Managing stem rust of wheat. Plant Pathology, Department of Agriculture, Western Australia. Farmnote, 73/2004.

CIMMYT E-News 2009. From Cairo to Kabul: Rust resistant wheat seed just in time. vol 6 no. 6 , October 2009.

Curtis BC 2002. Wheat in the world. In: Curtis B C, Rajaram S, Macpherson H G, eds. Bread wheat improvement and production. FAO Plant Production and Protection Series. Rome, FAO, 119.

El-Daoudi YH, Ikhlass Shafik, Bassioni AA, Sherif S, Khalifa MO 1987. Genes conditioning resistance to wheat leaf and stem rusts in Egypt. Proceeding $5^{\text {th }}$ Congress. Egypt. Phytopathology Society, 387-404.

Flor HH 1971. Current status of the gene-for-gene concept. Annual Review of Phytopathology, (9): 275-296.

Gomez KA, Gomez AA 1984. Statistical Procedures for Agricultural Research. $2^{\text {nd }}$ Edition, John Wiley and Sons Inc., New York. 
Jin Y, Singh RP, Ward RW, Wanyera R, Kinyua M, Njau P, Fetch T, Pretorius ZA, Yahyaoui A 2007. Characterization of seedling infection types and adult plant infection responses of monogenic $\mathrm{Sr}$ gene lines to race TTKS of Puccinia graminis f. sp. tritici. Plant Dis., (91): 1096-1099.

Jin Y, Szabo LJ, Pretorius ZA, Singh RP, Ward R, Fetch T. 2008. Detection of virulence to resistance gene Sr24 within race TTKS of Puccinia graminis f. sp. tritici. Plant Dis., (92): 923-926.

Klindworth DL, Miller JD, Williams ND, Xu SS 2011. Resistance of recombination stem rust race TPPKC in hard red spring wheat. Theoretical and Applied Genetics, (123):159-167.

Knott DR, Anderson RG 1965. The inheritance of stem rust resistance. 1. The inheritance of stem rust resistance in ten varieties of common wheat. Canadian Journal of Agricultural Science, (36): 174-195.

Kolmer JA, Jin Y, Fong DL 2007. Wheat leaf and stem rust in the line states. Australian Journal of Agricultural Research, (58): 631-638.

Liu SX, Yu LX, Singh RP, Jin Y, Sorrells ME, Anderson JA 2010. Diagnostic and co-dominant PCR markers for wheat stem rust resistance genes Sr25 and Sr26. Theoretical and Applied Genetics,(120): 691-697.

Luig NHJ, Latter BDH 1983. A new international classification system for Puccinia graminis tritici. Page 138 in Proceeding $4^{\text {th }}$ International Congress of Plant Pathology, Melburne, Australia.

Ma H, Singh RP, Kazi-Mujeeb A 1995. Resistance to stripe rust in Triticum turgidum, T. tauschii and synthetic hexaploids. Euphytica, (82): 117-124.

McVey DV, Long DL, Roberts JJ 2002. Races of Puccinia graminis in United States during 1997 and 1998. Plant Dis., (86): 568-572.
MSTAT-C 1991. A Software Program for Design, Management and Analysis of Agronomic Research Experiments, Michigan State University, pp. 400.

Nazari K, Mafi M, Yahyaoui A, Singh RP, Park RF 2009. Detection of wheat stem rust (Puccinia graminis f. sp. tritici) race TTKSK (Ug99) Iran. Plant Dis., (93): 317.

Ouda Samiha AH, Zohry A 2017. Crops intensification to reduce wheat gap in Egypt. In: Ouda, Samiha AH; A Zohry; Huda Alkitkat; M Morsy; T Sayad and A Kamel. Future of food gaps in Egypt obstacles and opportunities. Springer, Cham, Switzerland.

Pandey HN, Menon TC, Rao MV 1989. A single formula for calculating area under disease progress curve. Rachis, (8): 38-39.

Patpour M, Hovmøller MS, Shahin AA, Newcomb M, Olivera P, Jin Y, Hodson D, Nazari K, Azab M. 2016. First report of the Ug99 race group of wheat stem rust, Puccinia graminis f. sp. tritici, in Egypt in 2014. Plant Dis., (100): 863.

Pretorius ZA, Singh RP, Wagoire WW, Payne TS 2000. Detection of virulence to wheat stem rust resistance gene Sr31 in Puccinia graminis f. sp. tritici in Uganda. Plant Dis., (84): 203.

Roelfs AP, Martens JW 1988. An international system of nomenclature for Puccinia graminis f. sp. tritici. Phytopath., (78): 526-533.

Roelfs AP, Singh RP, Saari EE 1992. Rust diseases of Wheat: concept and Methods of Diseases Management. CIMMYT, 81.

Shahin AA 2002. Studies on stem rust disease of wheat and it's control in Egypt. Agriculture Faculty, Kafrelsheikh University, 93 p.

Shahin AA, Abu Aly A 2015. Physiological races of Puccinia graminis f. sp. tritici and situation of some resistance monogenic lines to stem rust in Egypt. Journal of Agricultural Research Kafrelsheikh University, (41):15-26. 
Shahin AA, Hasan MA, Abou-Zeid MA 2018. Adult plant resistance to stem rust and molecular marker analysis of some Egyptian and exotic bread wheat genotypes. Journal of Plant Protection and Pathology, (9): 901-907.

Singh RP, Hodson DP, Huerta-Espino J, Jin Y, Njau P, Wanyera R, Herrera-Foessel SA, Ward RW 2008. Will stem rust destroy the world's wheat crop. Advances in Agronomy, (98): 271-309.

Singh RP, Hodson DP, Huerta-Espino J, Jin Y, Bhavani S, Njau P, Herrera Foessel S, Singh PK, Singh S, Govindan V 2011. The emergence of Ug99 races of stem rust fungus is a threat to world wheat production. Annual Review of Phytopathology, (49): 465-481.

Singh RP, Hodson DP, Jin Y, Lagudah ES, Ayliffe MA, Bhavani S, Rouse MN, Pretorius ZA, Szabo LJ, Huerta-Espino J. Basnet BR, Lan C, Hovmøller MS 2015. Emergence and spread of new races of wheat stem rust fungus: continued threat to food security and prospects of genetic control. Phytopathology, (105): 872- 884.

Singh RP, William HM, Huerta-Espino J, Rosewarne G, 2004. Wheat rust in Asia: Meeting the challenges with old and new technologies. In "New Directions for a Diverse Planet: Proceedings of the 4th International Crop Science Congress" (accessed on April 18, 2013). September 26 October 1, Brisbane, Australia.

Stakman EC, Levine MN. 1922. The determination of biologic forms of Puccinia graminis on Triticum spp. Minn. Agric. Exp. Stn. Tech. Bull., 8 pp.

Stakman EC, Stewart DM, Loegering WQ 1962. Identification of physiologic races of Puccinia graminis var. tritici. USDA Agricultural Research Service Bulletin E., 617-53 pp.

Wiese MV 2005. Compendium of wheat diseases. 2nd ed. St. Paul, USA: American Phytopathological Society Press, 112 3. Oerke E C. Crop losses to pests. Journal of Agricultural Sciences, (144): 3143.
Youssef IA, Gamalat A Hermas, Doaa R Naggar, Nabila A El-Sherif 2012. Virulence of Puccinia graminis f. sp. tritici and postulate resistance genes for stem rust in thirteen wheat varieties during 2008/09 growing seasons in Egypt. Egyptian Journal of Applied Sciences, (27): 222-231. 